\title{
Analisis Perbandingan Fitur Search Engine
}

\author{
Fahmi Amrullah, Anharits Pantito, Ahmad Fauzi, Adheraprabu Bagaskhara, Zandhytama, Prof. Dr. \\ Saiful Bukhori, ST., M.Kom \\ saiful.ilkom@unej.ac.id \\ Fakultas Ilmu Komputer, Univeristas Jember
}

\begin{abstract}
Search engines are used in the web as a tool for information retrieval. Web Server is a large warehouse of heterogeneous and unstructured data so that to filter out relevant information from people, a search engine is needed. Search engines usually consist of page repositories, indexing modules, query modules and ranking modules. Search engines do not work alone, besides that there is a web browser that supports the work of this search engine to be more optimal. A browser is software that is run on a user's computer (user) that displays web documents or information taken from a web server [1]. A browser is the type of intermediary the user uses most often. This paper aims to analyze three search engines namely Google, Yahoo, and Bing based on existing features. These features include web search, image search, video search, news search, route search, book search, change search settings, display number of views, shopping, language translator. Google stands as the best search engine among all search engines, which works using the Page Rank algorithm. Page Rank is a numerical value that determines the importance of a web page by calculating the number of backlinks.
\end{abstract}

Keyword: Search Engine, Page Rank, Web Browser

\section{Introduction}

Mesin pencari pertama "Archie" dikembangkan pada tahun 1990 oleh Alan Emtage, seorang mahasiswa McGill University di Montreal, yang dikembangkan adalah kumpulan file komputer yang tersimpan di situs web FTP yang tidak dikenal di jaringan komputer [2] Pada tahun 1991, Mark McCahill, seorang mahasiswa University of Minnesota, secara efektif menciptakan Gopher menggunakan paradigma hypertext yang juga mencari referensi teks biasa dalam file.

Kedua mesin pencari ini tidak memiliki kemampuan kata kunci yang digunakan di mesin pencari modern. Oleh karena itu Hance pada tahun 1993 memperbaiki antarmuka grafis berbasis teks Gopher yang berbasis grafis Mosaic. Hampir bersamaan, Matthew Gray mengembangkan Wandex, mesin pencari pertama dalam bentuk mesin pencari modern. Teknologi Wandex adalah yang pertama menggunakan crawling of web, dan mencari katalog halaman yang terindeks di web. Perkembangan hebat lainnya di mesin pencari datang pada tahun 1994 ketika mesin pencari WebCrawler mulai mengindeks teks lengkap dari situs web, bukan hanya judul halaman web. Dari situlah banyak mesin pencari yang dikembangkan dengan cepat dan membuat merek mereka di pasar mesin pencari.

\section{Research Method}

Penelitian yang dilakukan tentang identifikasi perbandingan tiga perusahaan besar mesin pencarian yaitu, Google, Yahoo, dan Bing. Setiap hari terjadi sekitar 6.586.013.574 pencarian di seluruh dunia pada tahun 2017, pada posisi pertama ditempati Google dengan 4.464.000.000 pencarian per hari, kedua Bing dengan 873 juta pencarian, dan berikutnya Yahoo 536 juta pencarian per hari[3]. Pada tahun 2012 ketiga mesin pencari ini memiliki jumlah pengguna terbanyak dari mesin pencari lain. Dalam sebuah study yang dilakukan Chitika didapat prosentasi seperti tabel berikut : 


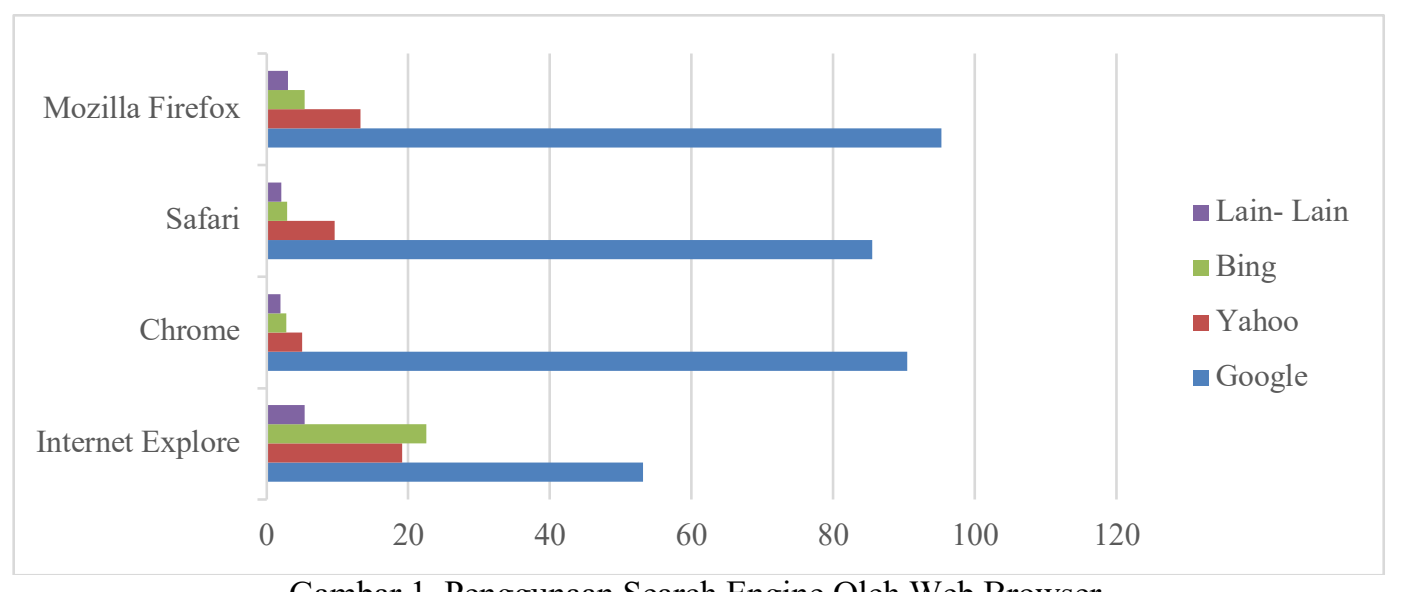

Gambar 1. Penggunaan Search Engine Oleh Web Browser

Dari empat web browser Google menempati semua posisi satu pemakaian terbanyak. Sekitar $75 \%$ mesin pencari Google digunakan oleh pengguna internet[3]. Pada umumnya semua mesin pencari digolongkan menjadi beberapa tipe diantaranya :

Crawler based Search Engine: adalah mesin pencari yang menggunakan program perangkat lunak yang disebut spider / crawlers / robots / bots. Setelah mengakses halaman web mereka dikategorikan dan dianalisis dan kemudian ditambahkan ke database pencarian, dimana pengguna dapat menemukannya nanti. Mesin pencari ini terus diperbarui dengan halaman web baru yang akan tersedia di database mereka [4].

Directories: Directories adalah website yang berisi kumpulan domain yang dikelompokkan berdasarkan kategori dan subkategori. Kategorisasi ini bukan dilakukan oleh webCrawler tetapi oleh manusia, biasanya didasarkan pada seluruh situs web lebih dari satu halaman atau satu set kata kunci, dan situs-situs yang sering terbatas pada masuknya hanya dalam beberapa kategori. Direktori Web sering memungkinkan pemilik situs untuk submit situs mereka untuk dimasukkan [5].

Meta- Search Engine: adalah mesin pencari yang menggabungkan semua hasil dari mesin pencari lainnya ke dalam satu daftar besar. Hasil pencarian yang didapat bisa diintegrasikan, duplikat bisa dihilangkan dan pengelompokan oleh subjek dalam hasil pencarian bisa diimplementasikan oleh mesin pencari meta[6].

Google, Yahoo, dan Bing menggunakan Crawler based Search Engine, tetapi ketiganya mempunyai cara kerja atau algoritma yang berbeda dalam memproses hasil pencariannya.

Google, secara garis besar ada tiga langkah yang dilakukan oleh google untuk melakukan pencarian. Ketiga langkah tersebut adalah Crawling dan Indexing, algoritma, Fighting Spam. Crawling proses mengumpulkan informasi dari sebuah website, setelah proses Crawling selesai dilanjutkan Indexing untuk mengatur hasil crawling ke dalam database. Algoritma Google akan bekerja mengandalkan lebih dari 200 rujukan informasi, sehingga memungkinkan untuk menebak informasi apa yang benar-benar anda cari dari kata kunci yang di masukkan. Fighting Spam yang dilakukan google mencegah konten yang tidak relevan tidak masuk ke dalam hasil pencarian.

Yahoo, sebagai mesin pencari Yahoo! Search langsung mencari dari miliaran jenis dokumen web yang tersebar dari berbagai situs. dalam menentukan peringkat hasil pencarian yang relevan dari halaman web untuk sebuah pencarian kata kunci tertentu, yaitu dengan menganalisis konten halaman web teks, judul, dan deskripsi serta sumber, link terkait, dan karakteristik lain dokumen unik.

Bing, bekerja dengan cara menyimpan informasi tentang banyak halaman web, yang diambil langsung dari World Wide Web. Halaman-halaman ini diambil dengan web crawler, browser web otomatis yang mengikuti setiap pranala yang dilihatnya. Isi setiap halaman lalu dianalisis untuk menentukan cara mengindeksnya (misalnya, kata-kata diambil dari judul, subjudul, atau field khusus yang disebut meta tag).

\section{Result and Analysis}

Didapatkan perbedaan fitur yang dimiliki ketiga mesin pencari. Setiap mesin pencari memiliki kekurangan dan kelebihan tersendiri dari fitur yang dimiliki. Perbedaan fitur ini dapat dilihat pada tabel 1.

TABEL I PERBANDINGAN FITUR SEARCH ENGINE.

\begin{tabular}{|c|c|c|c|}
\hline Fitur & Google & Yahoo & Bing \\
\hline
\end{tabular}




\begin{tabular}{|l|c|c|c|}
\hline \multicolumn{1}{|c|}{ Website } & www.google.com & www.yahoo.com & www.bing.com \\
\hline Pencarian Web & ya & ya & ya \\
\hline Pencarian Gambar & ya & ya & ya \\
\hline Pencarian Video & ya & ya & ya \\
\hline Pencarian Berita & ya & ya & ya \\
\hline Pencarian Peta & ya & tidak & ya \\
\hline Pencarian Buku & ya & ya & tidak \\
\hline Pencarian Lainnya & ya & tidak & ya \\
\hline Pengaturan Latar Belakang & ya & ya & ya \\
\hline Pengaturan Pencarian & ya & ya & ya \\
\hline Search Result & ya & tidak & ya \\
\hline Layanan Penerjemah & ya & tidak & tidak \\
\hline Mendukung Banyak Bahasa & ya & ya & tidak \\
\hline Tanya / Jawab & tidak & ya & tidak \\
\hline Petunjuk & ya & ya & tidak \\
\hline Iklan & ya & ya & tidak \\
\hline Case Sensitive & tidak & ya & ya \\
\hline Pencarian Aman & ya & ya \\
\hline Pengaturan Tampilan & ya &
\end{tabular}

\section{Conclusion}

Saat ini, mesin pencarian yang digunakan untuk mengambil informasi berbasis query yang relevan dalam beberapa detik oleh pengguna. Jurnal ini berusaha memberikan ulasan tiga mesin pencari (Google, Yahoo, Bing). Dari hasil penelitian fitur dari ketiga search engine di temukan bahwa untuk saat ini Google adalah search engine yang memiliki paling banyak fitur, yakni Google memiliki 17 dari 19 fitur yang ada, sedangkan untuk Yahoo dan Bing sendiri hanya memiliki 13 fitur dari 19 fitur yang ada. Akibatnya Google muncul sebagai mesin pencari terbaik. Inti dari Google adalah algoritma PageRank. Page Rank adalah cara Google menentukan pentingnya halaman. Google menghitung pentingnya halaman dari pemungutan suara untuk itu. Pentingnya setiap vote diperhitungkan saat page Page Rank dihitung.

\section{Acknowledgements}

Penelitian ini merupakan output dari salah satu mata kuliah yang telah ditempuh pada program studi sistem informasi fakultas ilmu komputer dengan dosen pembimbing Prof. Dr. Saiful Bukhori, ST., M.Kom. Terimakasih kami sampaikan untuk teman teman pada kelompok dua.

\section{References}

[1] Rachman, A. N., Gufroni, A. I., Hiron, N., \& Rahmayanti, G. (2013). Analisis Perbandingan Performansi dan Pemilihan Web Browser. Snati, 17-21.

[2] Mark Knowles. (2008). Short History of Early Search Engines. Retrieved from http://www.thehistoryofseo.com/The-Industry/Short_History_of_Early_Search_Engines.aspx

[3] Allen, R. (2017). Search Engine Statistics 2017. Retrieved from https://www.smartinsights.com/search-enginemarketing/search-engine-statistics/

[4] Lavania, K. K., Jain, S., Gupta, M. K., \& Sharma, N. (2013). Google: A Case Study (Web Searching and Crawling). International Journal of Computer Theory and Engineering, 5(2), 337-340.

[5] McCoy, K. (2000). Search Engines, Subject Directories, and Meta-Search Engines

[6] Lalnunsanga, M. (2010). An introduction to to a Meta-meta-search Engine, 1-4. Retrieved from https://decibel.ni.com/content/docs/DOC-8983 